DOI: 10.32844/2222-5374-2020-104-2.52

УДК: 343.98:343.431

Фарима М. М., здобувач наукової лабораторії з проблем протидії злочинності Національної академії внутрішніх справ

\title{
ВИКОРИСТАННЯ СПЕЦІАЛЬНИХ ЗНАНЬ ПІД ЧАС РОЗСЛІДУВАННЯ ТОРГІВЛІ ДІТЬМИ АБО ІНШОЇ НЕЗАКОННОЇ УГОДИ ЩОДО дИТИНИ
}

У статті визначено, що Кримінальний процесуальний кодекс України регламентує використання спеціальних знань, що застосовують під час розслідування торгівлі дітьми або іншої незаконної угоди щодо дитини у таких формах: залучення спеціаліста до проведення слідчих (розшукових) дій та негласних слідчих (розшукових) дій; залучення експерта і проведення експертизи; надання консультацій спеціалістом. Доведено, що найпоширенішою формою застосування спеціальних знань у кримінальних провадженнях, розпочатих у зв'язку з торгівлею дітьми або іншої незаконної угоди щодо дитини, є залучення експерта та проведення експертизи. Розглянуто такі з них: криміналістичні (почеркознавча, технічна експертиза документів; трасологічна, дактилоскопічна; фототехнічна; відео-, звукозапису; матеріалів, речовин та виробів; молекулярно-генетична; комп'ютерно-технічна; психологічна; мистецтвознавча; медичні (експертиза тілесних ушкоджень; експертиза статевих станів). З'ясовано, що у науковій літературі немає однозначного вирішення питання щодо форм використання спеціальних знань у процесі розслідування торгівлі людьми. Проте ми поділяємо думки деяких авторів, які до основних форм застосування спеціальних знань і технічних засобів у межах розслідування аналогічних злочинів відносять: 1) безпосереднє використання суб'єктом кримінально-процесуальної діяльності при виконанні своїх процесуальних функцій щодо збирання, дослідження й оцінки доказів; 2) участь спеціалістів при провадженні слідчих (розшукових) дій (СРД); 3) призначення і провадження судових експертиз. Визначено, що основною метою проведення судової експертизи є сприяння повному $i$ швидкому розслідуванню злочинів, встановленню істини у кримінальному провадженні, дослідження певних об'єктів і явищ, отримання необхідних відомостей для встановлення обставин, що мають значення для прийняття правильних та обгрунтованих рішень, а також отримання таких нових фактичних даних, які досі ініціаторам проведення експертизи не були відомі та які іншим способом встановити неможливо. Загалом, експертиза проводиться для виявлення тих фактичних даних, які можуть підтвердити або спростувати факти, що мають юридичне значення.

Ключові слова: діти, торгівля дітьми, незаконна угода щодо дитини, розслідування, спеціальні знання, експертиза, експерт. 
Актуальність. Під час розслідування торгівлі дітьми або іншої незаконної угоди щодо дитини нерідко виникають ситуації, за яких слідчому для виконання поставлених перед ним завдань вкрай необхідним є отримання інформації доказового або хоча б орієнтуючого характеру, яка дозволить визначити подальші ефективні напрями розслідування та допоможе прийняти вагомі процесуальні рішення. Отримання вказаної інформації інколи $є$ неможливим без застосування спеціальних знань [1, с. 171-172].

Стан наукової розробки. Так, В. М. Галкін визначає спеціальні пізнання як знання, набуті в результаті фахової освіти чи професійного досвіду [2, с. 8]. На думку Г.М. Надгорного, спеціальними знаннями є знання, що отримані в результаті професійної підготовки з наукових, інженерних, виробничих спеціальностей, а також інші загальновідомі знання, необхідні для вирішення питань у справі [3, с. 42]. Такий підхід до розуміння терміна «спеціальні пізнання» також не розкриває повною мірою його змісту, оскільки в ньому не йдеться про галузі, в яких вони застосовуються, і про відмінність цих знань від усіх інших. А.А. Ейсман зауважує, що спеціальні знання - це знання не загальновідомі, не загальнодоступні, такі, що не мають масового поширення; іншими словами, це знання, якими володіє обмежене коло спеціалістів, причому очевидно, що глибокі знання в галузі, наприклад фізики, є у зазначеному значенні спеціальними для біолога [4, c. 91].

В.Н. Махов уважає, що А.А. Ейсман правильно підкреслив істотну ознаку спеціальних знань, а саме те, що вони $\epsilon$ не загальнодоступними і не загальновідомими [5, с. 55-56]. Таким чином, спеціальні знання повинні відрізнятися від знань повсякденних, тобто загальнодоступних і загальновідомих. Повсякденні знання у своїй сукупності утворюють повсякденну свідомість, що являє собою життєву практичну свідомість людей (масову й індивідуальну), яка виходить за межі будь-якої вузькоспеціалізованої, професійної галузі та є головною повсякденною пізнавальною діяльністю і регулятором людської поведінки та спілкування [6, с. 20].

Виклад основного матеріалу. Незважаючи на теоретичні розвідки в розробленні проблеми, у науці трапляються різні точки зору щодо того, які саме знання є спеціальними: по-перше, ці знання не є загальнодоступними, загальновідомими [4, с. 72]; по-друге, їх мають фахівці вузького профілю, які дістали спеціальну підготовку або набули практичний досвід роботи у відповідній галузі [7, с. 68-73]. Іноді надають надто широке визначення цього поняття за рахунок віднесення до спеціальних усіх фахових знань, наприклад: «економічні знання», «технічні знання», «медичні знання» тощо [8, с. 7]. Інколи спеціальні знання розуміють необгрунтовано вузько, відносячи до цієї категорії лише ті знання, що здобуті унаслідок спеціальної освіти $[9$, с. 12$]$.

На нашу думку, у науковій літературі немає однозначного вирішення питання щодо форм використання спеціальних знань у процесі розслідування торгівлі людьми. Проте ми поділяємо думки деяких авторів, які до основних форм застосування спеціальних знань і технічних засобів у межах розслідування аналогічних злочинів відносять: 1) безпосереднє використання суб'єктом кримінально-процесуальної діяльності при виконанні своїх процесуальних функцій щодо збирання, дослідження й оцінки 
доказів; 2) участь спеціалістів при провадженні слідчих (розшукових) дій (СРД); 3) призначення і провадження судових експертиз.

На думку Б. В. Романюка, форма реалізації спеціальних знань залежить насамперед від суб'єкта, виду діяльності та мети їх застосування [10, c. 8-9].

Вивчення матеріалів кримінальних проваджень засвідчило, що основними формами використання спеціальних знань при розслідуванні торгівлі дітьми або іншої незаконної угоди щодо дитини є:

- залучення спеціаліста до проведення СРД та негласних слідчих (розшукових) дій (НСРД), зокрема у таких кримінальних провадженнях залучалися судово-медичний експерт або лікар (82 \%); педагог, психолог (75 \%); спеціаліст у галузі медичних знань (48 \%); спеціаліст Експертної служби МВС України (13\%);

- залучення експерта і проведення експертизи;

- надання консультацій спеціалістом.

Говорячи про визначення судової експертизи, одразу слід зазначити, що воно надане у ст. 1 Закону України «Про судову експертизу» як «...дослідження експертом на основі спеціальних знань матеріальних об'єктів, явищ і процесів, які містять інформацію про обставини справи, що перебуває у провадженні органів досудового розслідував чи суду» [11].

Відповідно до ст. 1 Закону України «Про судову експертизу», судова експертиза - це дослідження на основі спеціальних знань у галузі науки, техніки, мистецтва, ремесла тощо об’єктів, явищ і процесів з метою надання висновку з питань, що $є$ або будуть предметом судового розгляду [11].

У свою чергу, В.Ю. Шепітько вказує, що судова експертиза - це процесуальна дія, яка полягає в дослідженні експертом за завданням слідчого або судді речових доказів та інших матеріалів 3 метою встановлення фактичних даних та обставин, що мають значення для правильного вирішення справи [12, с. 257].

У практичній діяльності, навчальній і науковій літературі термін «судова експертиза» трактується більш широко та має декілька значень. Залежно від того, на якому аспекті судово-експертної діяльності робиться акцент, під судовою експертизою розуміється інститут доказового й процесуального права, система процесуальних відносин, форма використання спеціальних знань, слідча (розшукова) дія, процедура дослідження й оформлений за результатами їі завершення документ висновок експерта [13, с. 357].

Основною метою проведення судової експертизи $\epsilon$ сприяння повному і швидкому розслідуванню злочинів, встановленню істини у кримінальному провадженні, дослідження певних об'єктів і явищ, отримання необхідних відомостей для встановлення обставин, що мають значення для прийняття правильних та обгрунтованих рішень, а також отримання таких нових фактичних даних, які досі ініціаторам проведення експертизи не були відомі та які іншим способом встановити неможливо. Загалом, експертиза проводиться для виявлення тих фактичних даних, які можуть підтвердити або спростувати факти, що мають юридичне значення. Самі по собі юридичні факти експертизою не встановлюються 
чи не виключаються, а тому не допускається проведення експертизи для 3'ясування питань права [14, с. 88-89].

В цілому, роль експертизи в розслідуванні злочинів полягає в тому, що вона: а) забезпечує отримання нових доказів; б) дозволяє вводити до процесу доказування фактичні дані, що для органолептичного сприйняття та дослідження недоступні; в) надає можливість перевіряти достовірність фактів, встановлених органолептичними засобами; г) дозволяє за матеріальними відображеннями вирішувати проблему ототожнення людей та речей [15, с. 341].

Серед таких експертиз важливе місце займають криміналістичні експертизи. O.I. Вінберг зазначав, що це один із видів судової експертизи, яка базується на даних криміналістики і полягає у дослідженні експертом речовин, доказів та інших матеріалів кримінальної або цивільної справи $з$ метою ідентифікації людини, тварин, транспортних засобів, інструментів і знарядь за їх слідами-відображеннями або за розділеними частинами цілого, а також у вирішенні спеціальних питань не ідентифікаційного характеру (за обставинами даної справи) [16, с. 15]. В.М. Глібко визначає криміналістичну експертизу як лабораторне дослідження об'єктів з метою встановлення їхнього фактичного стану; можливості проведення певних дій; обставин, за яких були проведені дії; невидимих слідів зашифрованого змісту; групової належності об'єктів або їх тотожності [17, с. 430].

Загальний процесуальний порядок залучення експерта та призначення і проведення експертиз регламентовано ст. 69, 70 та 242-245 КПК України і Законом України «Про судову експертизу» від 25 лютого 1994 р. [11]. Порядок відібрання зразків із речей і документів встановлено положеннями про тимчасовий доступ до речей і документів (ст. 160-166 КПК України). Відбирання біологічних зразків в особи здійснюють за правилами, передбаченими ст. 241 КПК України [18].

Експертом може будь-яка особа, яка має спеціальні пізнання в науці, техніці, мистецтві та ремеслі. Питання експертові мають бути конкретними, ясними, чіткими, без двоякого трактування. Питання, що виносяться на експертизу мають відноситися до компетенції експерта. Серед основних цілей використання спеціальних знань експертом під час експертизи К. О. Чаплинський виділяє сприяння повному і швидкому розкриттю та розслідуванню злочинів, встановлення істини у кримінальній справі, дослідження певних об'єктів і явищ, отримання необхідних відомостей для встановлення обставин, що мають значення для правильного та обгрунтованих рішень по справі; сприяння виявленню, фіксації і вилученню доказів та з'ясуванню спеціальних питань, що виникають при проведенні СРД [19, c. 236].

Під час проведення експертиз необхідно вжити заходів до пошуку додаткових та закріплення наявних доказів, ідо стосуються не лише фактичних обставин вчинення злочину, але й ступеню обізнаності з ним причетних до цього осіб для доведення їх умислу на вчинення злочину, а також перевірити версії про співучасть у злочинній діяльності посадових осіб державних органів, установ та організацій.

При розслідуванні торгівлі людьми для доведення вини підозрюваних, виявлення особи та стану потерпілого, інших обставин злочину сут- 
тєве значення має призначення судових експертиз. Зокрема криміналістичних, у тому числі почеркознавчих по вилученим документам, з метою встановлення виконавців підписів та рукописних текстів, технічних засобів, які використовувалися при складанні завідомо неправдивих документів і т.ін. Разом з тим, наприклад, за наявності даних про заподіяння потерпілим під час сексуальної експлуатації або при примушуванні до цього ушкоджень, зараження венеричною хворобою або вірусом імунодефіциту тощо, про звернення останніх у зв'язку з цим до медичних установ необхідно проводити судово-медичні експертизи з метою встановлення характеру і тяжкості заподіяних тілесних ушкоджень, оскільки їх висновки можуть мати суттєве значення для кваліфікації дій злочинців, як за відповідними частинами ст. 149 КК України, так і за іншими статтями. У ряді випадків, за наявності достатніх підстав, для встановлення тяжкості вчиненого злочину і для визначення заподіяної потерпілій особі шкоди, може виникнути необхідність у проведенні судово-психіатричних та судово-психологічних експертиз щодо визначення психічного стану потерпілих. Якщо, наприклад, потерпілий звернувся до правоохоронних органів через деякий час, коли спеціалісти не зможуть в повній мірі визначити фізичну або психологічну шкоду, що йому заподіяна, важливо встановити, до яких медичних закладів звертався потерпілий (якщо цей факт взагалі мав місце). Указані обставини підлягають обов'язковій перевірці шляхом вивчення відповідних медичних документів (реєстраційних обліків, карток, історій хвороб), а також шляхом допиту медичних працівників. Під час проведення експертиз необхідно вжити заходів до пошуку додаткових та закріплення наявних доказів, що стосуються не лише фактичних обставин вчинення злочину, але й ступеню обізнаності з ним причетних до цього осіб для доведення їх умислу на вчинення злочину, а також перевірити версії про співучасть у злочинній діяльності посадових осіб державних органів, установ та організацій $[20$, с. 95].

Аналіз слідчої практики свідчить про те, що не всі сучасні можливості судових експертиз і не весь їхній існуючий спектр використовується при розслідуванні таких злочинів. 3 метою отримання даних для додаткової кваліфікації за ознаками інших видів злочинів, пов'язаних з торгівлею людьми, можуть бути призначені судово-медичні експертизи для встановлення статевої зрілості потерпілого (ст. 155 КК України), наявності у нього слідів насильницького статевого акту (ст. 152 КК України), тілесних ушкоджень (ст. 127 КК України) тощо.

Крім наведених обов'язкових випадків проведення медичних, психологічних і психіатричних досліджень, відповідні експертизи призначаються при розслідуванні торгівлі людьми и для встановлення інших обставин кримінального правопорушення: правильності сприймання потерпілим обставин, що мають значення у кримінальному провадженні, спроможності давати про них відповідні показання; емоційного стану потерпілого в період, який передував його самогубству; психотравмуючої ситуації для потерпілого; впливу ситуації в сім'ї та виховної поведінки батьків на емоційний стан, психічний розвиток дитини; спричинення страждань (моральної шкоди); індивідуально-психологічних особливостей і психічних захворювань осіб, які проходять у кримінальному провадженні тощо. 
Експертне психологічне дослідження підозрюваного у кримінальних провадженнях про торгівлю людьми, як правило, проводиться в таких взаємопов'язаних напрямках: 1) діагностика стійкої системи мотивів, широти відображення в них існуючих у суспільстві сфер відносин, стійкості привідних спонукань, їхньої ієрархічності, змісту, співвідношення з вимогами суспільства; 2) дослідження характеру, особистих захисних механізмів, стереотипів поведінки, звичайних способів адаптації до труднощів, особливостей пізнавальної сфери (мислення, уяви, пам'яті, сприйняття, темпів перебігу психічних процесів); 3) установлення індивідуально-рольового статусу підозрюваних у злочинній групі (лідер, підлеглий, ведений тощо) [21, с. 41].

Крім зазначених, при розслідуванні торгівлі людьми найбільш поширеними $є$ такі різновиди криміналістичних експертиз:

- технічна експертиза документів, за допомогою якої можна встановити спосіб їхнього виготовлення або підроблення (наприклад, заміну фотографії дитини в документі), визначити спосіб унесення в них змін і доповнень (наприклад, дописування в історії хвороби дитини); установити зміст виведеного тексту (відновити початковий текст у підробленому паспорті), ототожнити кліше печаток і штампи органів піклування, інших державних установ, установити обладнання, на якому виготовлювався документ тощо;

- почеркознавча експертиза, за допомогою якої встановлюється виконавець рукописного тексту, цифрових записів або підписів у різній документах - контрактах, чорнових записах, заявах, документах про всиновлення тощо;

- трасологічна експертиза з метою ідентифікації особи за відбитками пальців рук, цілого за частинами (у разі виявлення при огляді місця події, обшуку, виїмки уламків, обривків, осколків, частин упаковок, матеріалів, що $є$ східними з тими, у яких знаходилися або були виявлені в інших місцях частини певних предметів, речовин);

- портретна експертиза з ототожнення особи за фотографією, відеозаписом (у тому числі за зображенням в Інтернеті). у деяких випадках рекомендується ідентифікувати особу не тільки за ознаками обличчя, а в разі його відсутності на фотографії й за іншими ділянками тіла, що мають родимки, папіломи, рубці, інші дефекти на шкірі;

- експертиза матеріалів, речовин та виробів: наркотичних речовин (установлення класифікаційної належності виявлених речовин); волокнистих матеріалів (наприклад, волокнами на одязі малолітнього чохла автомобіля, яким його перевозили) тощо.

Можна з упевненістю констатувати той факт, що при розслідуванні торгівлі людьми майже не призначаються менш поширені види експертиз, які можуть забезпечити слідчого незамінною доказовою інформацією. При розслідуванні торгівлі новонародженими важливо встановити батьків, яким було повідомлено про нібито смерть їхніх дітей. У вирішенні цього питання не можна обійтися без проведення експертизи, основним методом якої $є$ ДНК-аналіз крові порівнюваних осіб. Стратегія «встановлення родичів» заснована на тому, що профілі ДНК близьких кровних родичів мають подібність, у криміналістичній і експертній літературі найменування 
цієї експертизи ще не встановилося й вона розглядається як вид судово-медичної експертизи, іменується судово-генетичною, геномною, молекулярно-генетичною, генотипоскопічною. Теоретичну базу для встановлення спорідненості добре розроблено в генетиці.

Кваліфікуюче значення при розслідуванні торгівлі людьми має встановлення форми співучасті злочинців у вчиненні злочину - групою осіб, за попередньою змовою групою осіб, організованою групою, злочинною організацією (ст. 28 КК Україні). Вирішенню цього завдання може сприяти дослідження апаратів мобільного зв'язку, електронних записних книжок та інших магнітних носіїв інформації.

Мобільні телефони в сучасних умовах $є$ цінним джерелом доказової та орієнтуючої інформації, що, крім іншого, містять сліди злочину. Аналіз розслідування торгівлі людьми свідчить про те, що мобільні телефони фігурують майже в кожному кримінальному провадженні і $є$ важливим джерелом інформації. Крім мобільних телефонів, у підозрюваних вилучають й інші носії інформації, що використовуються в мобільних телефонах (SIM-картки та картки пам'яті тощо), які за певних умов також стають об'єктами дослідження. На жаль, слідчі недостатньо обізнані в можливостях експертизи комп'ютерної техніки та програмних продуктів. Так, у вилучених у ході розслідування мобільних телефонах можна виявити вміст пам'яті мобільного терміналу, SIM-картки, змінного носія інформації; інформацію стосовно з'єднань, звуко-, відеозаписів, повідомлень; зміст видаленої інформації на змінних носіях і SIM-картці та ін. Ще одним вагомим джерелом доказування при розслідуванні торгівлі людьми є висновок експертизи відеозвукозапису.

Разом з тим, під час проведення НСРД (наприклад, оперативної закупівлі) можуть використовуватися технічні засоби, за допомогою яких фіксуються мовлення та зовнішність злочинців. Для надання цим матеріалам доказового значення необхідно, по-перше, установити технологію отримання відео-звукозапису та відсутність у ньому ознак монтажу.

Для цього експерт має розв'язати завдання щодо встановлення відсутності змін у відеофонограмі, безперервності запису, запису на одному технічному пристрої та ін. Нині розроблено надійні експертні методики щодо встановлення факту монтажу або внесення часткових змін як в аналогових, так і в цифрових фонограмах.

Ще одним, не менш важливим завданням, є ототожнення певної особи за мовленням на фонограмі.

Підсумовуючи вищевикладене, з урахуванням вивчення кримінальних проваджень та практичного досвіду встановлено, що важливою формою застосування спеціальних знань у кримінальних провадженнях, розпочатих за фактом торгівлі дітьми, є залучення експерта та проведення експертизи. Особливе місце у розслідуванні таких злочинів належить:

1) криміналістичним експертизам: почеркознавча (рукописні тексти і підписи, вилучені під час обшуку чи огляду (боргові та інші розписки, договори з підписами, робочі записи обліку грошових коштів, здобутих злочинним шляхом тощо)); технічна експертиза документів (документи, що посвідчують особу, дають право на перетин кордону, проїзні документи; договори про працевлаштування; установчі документи фіктивних фірм, 
бюро тощо); трасологічна, дактилоскопічна (сліди, залишені дітьми під час їх викраденні та/або перевезенні, вилучені під час огляду, обшуку транспортних засобів, приміщень; сліди невстановлених співучасників злочину, залишені на документах, інших предметах); фототехнічна (фотознімки, кінофільми та відеозаписи, які містять відображення експлуатації дитини, зокрема у порнобізнесі; фото- та кіноапаратура, фотознімки, кінофільми, фото- та кіно матеріали, вилучені під час огляду, обшуку); відео-, звукозапису (оригінальна фонограма запису розмов, зокрема висловлених погроз насильством, шантажу, обману дитини, а також виготовлені матеріали порнографічного характеру у випадку експлуатації її в такий спосіб; оригінальний пристрій, яким фонограма зафіксована, додаткове обладнання); матеріалів, речовин та виробів (предмети одягу підозрюваного; грошові кошти, вилучені під час тактичної операції фіксації факту їх передачі за «живий товар», а також контрольні зразки); молекулярно-генетична (ідентифікація конкретної особи на основі генетичної інформації, що $\epsilon$ в біологічних частинках - шматочках шкіри, а також у рідинах - слині, крові, поту, з метою встановлення особливостей механізму вчинення злочину й перевірки версії щодо взаємозв'язку матеріальних об’єктів на місці події з ії учасниками;

2) комп'ютерно-технічна експертиза (встановлення слідів злочину або іншої значимої для кримінального процесу інформації);

3) психологічна експертиза (встановлення факту використання уразливого стану дитини, оцінки показань малолітніх, дітей-потерпілих);

4) мистецтвознавча експертиза (встановлення тотожності особи, зображеної на вилучених фотознімках або відеозаписах під час огляду, обшуку);

5) медичні експертизи: експертиза тілесних ушкоджень (дитини, до якої застосовувалось насильство або у випадку, коли експлуатація полягала у вилученні органів, проведенні дослідів над нею); експертиза статевих станів (дитини, коли експлуатація полягала у примусовій вагітності або примусовому перериванні вагітності).

Водночас, слідчим слід активніше застосовувати непроцесуальні форми використання спеціальних знань, наприклад консультації спеціалістів, експертів. Під час консультації можна отримати довідкові відомості, що стосуються певного виду експертизи: сучасні можливості експертного дослідження, правильне формулювання питань, перелік об’єктів, які необхідно надати експерту тощо.

\section{СПИСОК ВИКОРИСТАНИХ ДЖЕРЕЛ}

1. Загамула В. В. Методика розслідування втягнення неповнолітніх у заняття проституцією. Дис...канд.гюрид. наук : 12.00.09. Київ, 2019. 242 с.

2. Галкин В. М. Средства доказывания в советском уголовном процессе. Москва: ВНИИСЭ. 1968. Ч. 2.68 с.

3. Надгорный Г. М. Гносеологические аспекты понятия «специальные знания» Криминалистика и судебная экспертиза. Киев: Высш. шк., 1980. Вып. 21. С. 35-43.

4.Эйсман А.А.Заключениеэксперта. Структура и научное обоснование. Москва: Юрид. лит., 1967. 147 с. 
5. Махов В. Н. Использование знаний сведущих лиц при расследовании преступлений: монография. Москва: Изд-во РУДН, 2000. 296 с.

6. Пукшанский Б. Я. Обыденное знание. Ленинград: Изд-во Ленингр. гос. ун-та, 1987. 211 с.

7. Серов В. А. Специальные познания и формы их использования при расследовании и рассмотрении уголовных дел. Социалистическое развитие и право. Москва, 1980. С. 68-73.

8. Морозов Г. Е. Участие специалиста в стадии предварительного расследования: автореф. дис...канд. юрид. наук: 12.00.09 «Уголовный процесс и криминалистика; судебная экспертиза». Саратов, 1977. 20 с.

9. Сорокотягин И. Н. Криминалистические проблемы использования специальных познаний в расследовании преступлений: автореф. дис... докт. юрид. наук: 12.00.09 «Уголовный процесс и криминалистика; судебная экспертиза». Екатеринбург, 1992. 36 с.

10. Романюк Б. В. Сучасні теоретичні та правові проблеми використання спеціальних знань у досудовому слідстві: автореф. дис... канд. юрид. наук: 12.00.09. Київ, 2002. 20 с.

11. Про судову експертизу: Закон України від 25 лют. 1994 р. № 4038XII. Верховна Рада України: URL: http://zakon2.rada.gov.ua/laws/show/ $\mathrm{ru} / 4038-12$.

12. Криміналістика : підручник. Вид. 4-е перероб. і доп. / за ред. проф. В.Ю. Шепітька. Харків : Право, 2008. 464 с.

13. Тутецька Н. В. Судова експертиза як засіб доказування у кримінальному судочинстві Теорія $i$ практика судової експертизи $i$ криміналістики : матеріали Всеукраїнської науково-практичної конференції з нагоди 85-річчя доктора юридичних наук, професора Н. I. Клименко, 27 лют. 2018 р. Київ - Маріуполь. 2018. С. 357-359.

14. Паладійчук 0. Ю. Значення судової експертизи у вирішенні завдань кримінального провадження. Науковий вісник Ужгородського національного університету. Серія ПРАВО. 2015. Вип. 34. Т. 3. С. 87-89.

15. Криміналістика : підручник. Вид. 2-ге випр. і доп. / за ред. П.Д. Біленчукв. Київ : Атіка, 2001. 544 с.

16. Винберг А. И. Судебная экспертология (общетеоретические и методологические проблемы судебных экспертиз) : учеб. пособ. Волгоград: «Норма», 1978. 182 с.

17. Глібко В. М. Криміналістика : підручник / за ред. В. Ю. Шепітька. Київ: «Ін Юре», 2001. 684 с.

18. Кримінальний процесуальний кодекс України: Закон України від 13 квіт. 2012 р.

19. Чаплинський К. О. Тактика використання спеціальних знань у системі тактичного забезпечення досудового розслідування. Науковий вісник Дніпропетровського державного університету внутрішніх справ. 2011. №57. С. 232-238.

20. Виявлення та розслідування злочинів, пов'язаних з торгівлею людьми : метод. рек. для практ. працівників / Л.В. Черечукіна, М.О. Яковенко; Луган. держ. ун-т внутр. справ ім. Е. О. Дідоренка. Луганськ : РВВ ЛДУВС ім. Е.0. Дідоренка, 2013. 135 с. 
21. Костицький М. В. Використання спеціальних психологічних знань у радянському кримінальному процесі. Київ: НМК ВО, 1990. 58 с.

\section{Faryma}

\section{USE OF SPECIAL KNOWLEDGE DURING INVESTIGATION TRAFFICKING CHILDREN OR ANOTHER ILLEGAL AGREEMENT ON A CHILD}

The article stipulates that the Criminal Procedure Code of Ukraine regulates the use of special knowledge used in the investigation of child trafficking or other illegal agreement on a child in the following forms: involvement of a specialist in investigative (investigative) actions and covert investigative (investigative) actions; involvement of an expert and examination; providing consultations by a specialist. It has been proven that the most common form of application of special knowledge in criminal proceedings initiated in connection with child trafficking or other illegal agreement concerning a child is the involvement of an expert and examination. The following are considered: forensic (handwriting, technical examination of documents; trasological, dactyloscopic; phototechnical; video, sound recording; materials, substances and products; molecular genetic; computertechnical; psychological; art criticism; medical (examination of bodily injuries; examination of sexual conditions). It has been found that there is no unambiguous solution in the scientific literature on the use of specialized knowledge in the investigation of human trafficking. However, we share the views of some authors, which the main forms of application of special knowledge and technical means in the investigation of similar crimes include: 1) direct use of the subject of criminal procedure in performing its procedural functions for collecting, researching and evaluating evidence; 2) participation of specialists in conducting investigative (search) actions; 3) appointment and conduct of forensic examinations. It is determined that the main purpose of forensic examination is to facilitate a full and rapid investigation of crimes, establish the truth in criminal proceedings, study certain objects and phenomena, obtain the necessary information to establish the circumstances relevant to making correct and reasonable decisions, and such new factual data, which were not yet known to the initiators of the examination and which cannot be established in any other way. In general, the examination is conducted to identify those facts that can confirm or refute the facts that have legal significance.

Keywords: children, child trafficking, illegal agreement on a child, investigation, special knowledge, expertise, expert. 